\title{
Contenção de Custos e QuALIDADE dO ATENDIMENTO
}

custo da assistência médica mostra uma evolução crescente ao longo dos anos, e esse fato é, em grande parte, responsável pelo aumento do gasto com saúde na maiora dos países. Em proporção do Produto Interno Bruto, o gasto com saúde nos Estados Unidos, para dar apenas um exemplo, passou de cerca de $6 \%$ em meados dos anos 60 para I 4\% atualmente. A continuar essa tendência, o peso da saúde na economia americana se tornaria rapidamente insustentável. Desde já, o custo com a saúde dos trabalhadores representa até 20\% do custo de produção em alguns setores produtivos naquele país. Esse fenômeno, com as devidas diferenças, se repete nos demais países, e o Brasil não é exceção.

Assim, é imperativo que se identifiquem as causas do crescimento dos custos em saúde, e que se adotem medidas para controlá-lo e contê-lo. Todos os países vêm demonstrando essa preocupação, tanto do lado das autoridades sanitárias quanto entre prestadores e instituições financiadoras (por exemplo, os planos de saúde em nosso país). Entretanto, o receio é de que ao controlar os custos da assistência médica e conter o seu crescimento, tenhamos que sacrificar a qualidade dos serviços. Essa é uma crença bastante difundida entre os profissionais da saúde.

Na realidade, essa é uma grande simplificação, e é apenas parcialmente verdade. É claro que se um prestador de assistência médica - seja ele público ou privado decidir cortar custos indiscriminadamente, sem conhecer os fatores que contribuem para esses custos e sem um planejamento cuidadoso, é muito provável que a qualidade seja prejudicada. Porém, essa é sem dúvida uma maneira inadequada, e muitas vezes suicida, de se reduzir custos.

Quando se conhecem os fatores responsáveis pelos desperdícios e ineficiências existentes no processo de produção dos serviços de saúde, pode-se perceber que esses são com freqüência também fatores que prejudicam a qualidade da assistência. Daremos a seguir alguns exemplos. 0 gerenciamento inadequado num hospital que causa falhas no aprovisionamento em determinado medicamento, provocará ao mesmo tempo um aumento no custo da assistência (ao aumentar o tempo de permanência do paciente e exigir uma compra emergencial do referido medicamento) e uma deterioração da qualidade (ao prejudicar ou adiar o tratamento do paciente e fazê-lo permanecer desnecessariamente no hospital sujeito a infecções hospitalares). Um equipamento sem manutenção adequada atrasará ou impedirá o tratamento de determinados pacientes, com reflexos simultâneos sobre o custo do tratamento e a qualidade da assistência. Uma alta taxa de infecção hospitalar resulta, ao mesmo tempo, em altos custos e em má qualidade. Finalmente, a utilização excessiva ou desne- cessária de alta tecnologia certamente acarreta custos desnecessários, mas também, com freqüência, resulta em queda na qualidade da assistência prestada.

Desta forma, em muitos casos são os mesmos os fatores responsáveis pelos altos custos e pela baixa qualidade dos serviços de saúde. Eles são em parte conseqüência de um gerenciamento insuficiente ou inadequado dos serviços de saúde, e de uma despreocupação, muito comum entre profissionais de saúde, com o custo dos serviços e sua eficiência. Era comum até pouco tempo atrás ouvirmos afirmações como "saúde não tem preço".

Como a prestação de serviços de saúde obviamente exige a utilização de recursos, em quantidade vultosa como vimos, essa postura tem levado muitas vezes a um custo desnecessariamente alto da assistência médica. Uma política esclarecida e planejada de identificação das ineficiências e desperdícios no processo de produção permitirá ao mesmo tempo reduzir ou eliminar os custos desnecessários e melhorar a qualidade da assistência médica. $O$ controle de custos e a busca da qualidade não devem, portanto, ser considerados como mutuamente exclusivos ou mesmo objetivos concorrentes, mas sim duas facetas do mesmo processo, cada vez mais necessário, de gerenciamento da assistência médica, que busca encontrar maneiras mais eficientes e racionais de melhorar e manter a saúde da população. 